\title{
Provenance and tectonic setting of Miocene clastic sedimentary rocks from the Baguio District, Luzon, Philippines : Evidence from major and trace element geochemistry
}

\author{
Tomas A. Tam III***, Shigeyuki Suzuki* and Graciano P. Yumul Jr.**,***
}

\begin{abstract}
Major and trace element geochemistry of Miocene sandstones and shales from the Baguio District, Luzon, Philippines have been analyzed to determine their provenance and tectonic setting. Major element discrimination plots (e.g. $\mathrm{SiO}_{2}-\mathrm{K}_{2} \mathrm{O} / \mathrm{Na}_{2} \mathrm{O}$ ) reveal mafic volcanic arcs as possible source rocks. Elemental ratios critical of provenance $(\mathrm{Th} / \mathrm{Sc}, \mathrm{Zr} / \mathrm{Sc})$ mainly reveal an active continental margin signature for the Zigzag Formation and an oceanic island arc for the Klondyke Formation. These results support earlier studies that the Baguio District had evolved from a marginal basin environment to a mature island arc setting.
\end{abstract}

Key words : provenance, miocene, Philippines, geochemistry

\section{Introduction}

The application of geochemistry on sedimentary rocks in identifying provenance and tectonic setting is primarily based on the relative mobility of major, trace and rare earth elements within surficial environments (Taylor and McLennan, 1985). Certain elements are generally thought to be quantitatively transported into clastic sedimentary rocks after weathering, and therefore may reflect the signature of the parent materials.

Using major and trace element data, different authors assigned fields based on the premise that sedimentary rocks preserve the source region character of the rocks from where they were eroded. Various discrimination diagrams suitable for the determination of provenance and tectonic setting are available (e.g. Taylor and McLennan, 1985). In this study, the major and trace element

Received ; October 27, 2006 ; Accepted : January 15, 2007

* Department of Earth Sciences, Okayama University, 3-1-1 Tsushima-naka, Okayama 700-8530, Japan, E-mail : tamtomaz $81 @$ yahoo.com

** National Institute of Geological Sciences, College of Science, University of the Philippines, Diliman, Quezon City, Philippines

*** Philippine Council for Industry and Energy Research and Development, Department of Science and Technology, Bicutan, Taguig, Metro Manila, Philippines compositions of Miocene sandstones and shales from the Zigzag and Klondyke Formations of the Baguio District, Luzon, Philippines have been investigated to determine provenance and tectonic setting.

\section{Geologic Setting}

The Baguio District is part of the Central Cordillera magmatic arc of Luzon Island, which exemplifies the complex volcano-plutonic, and geodynamic evolution that the Philippine archipelago has undergone (e.g. Bellon and Yumul, 2000). The area exposes igneous, metamorphic and sedimentary rock types formed from the interaction of several tectonic features. For the purpose of this study, we collected sandstone and shale samples from two formations in the study area : the Zigzag and Klondyke Formations. These units were chosen not only because of their wide distribution but also because of their unique positions in the stratigraphy of the area which are critical in deciphering and understanding the geology of the region (Fig. 1).

The early Miocene Zigzag Formation is generally composed of interbedded green sandstones and red siltstones, oligomictic conglomerates and minor limestone units. The formation is inferred to have been deposited when the basin was still very young and deep (Peña and Reyes, 1970). The red and green beds are believed to be the 


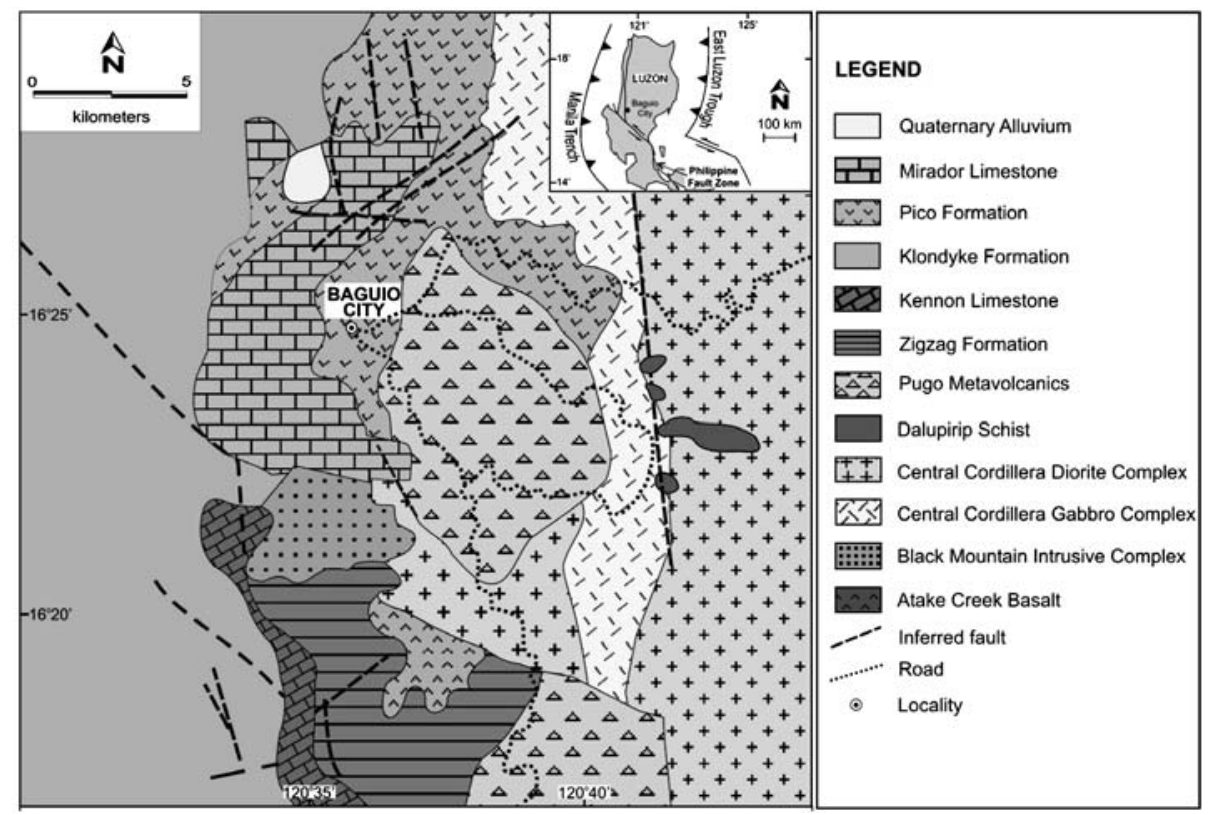

Fig. 1 Geologic map of the Baguio District modified from Bellon and Yumul (2000). Miocene sandstones and shales from the Zigzag and Klondyke Formations are the focus of this study.

response of the sediments to fluctuating depths of a basin. This resulted to the oxidation of the rocks and caused the changes in the color of the sandstones. The late early Miocene to Early Middle Miocene Kennon reefal limestone conformably overlies the Zigzag Formation (Bellon and Yumul, 2000), and is, in turn, unconformably overlain by the Middle to Late Miocene Klondyke Formation.

On the other hand, the Klondyke Formation is described as a thick sequence of coarse clastic rocks, polymictic conglomerate, conglomeratic sandstones, massive sandstones, and flow breccias, vitric tuffs, with minor shales and siltstones (Tamesis et al., 1982). This formation is mainly composed of several submarine fan deposits divided into proximal, mid-fan and distal units. These units are made up of (from proximal to distal) clastsupported polymictic conglomerates, thickly bedded turbiditic sandstones and shales.

\section{Results}

Representative fine-grained sandstone and shale samples obtained from these formations were analyzed for major and trace elements by X-ray Fluorescence Spectrometry (XRF) and Inductively Coupled Plasma Mass Spectrometry (ICP-MS). The major and trace element geochemistry of the clastic rocks provides consistent provenance clues for the Baguio District.

\section{Provenance}

The provenance of fine-grained sedimentary rocks can be deciphered by comparing it with those of sedimentary rocks deposited in known tectonic settings. Roser and Korsch (1986) have classified sandstones and shales into four provenance groups using major element discriminant function. The discriminant function uses $\mathrm{Al}_{2} \mathrm{O}_{3}, \mathrm{TiO}_{2}$, $\mathrm{TFe}_{2} \mathrm{O}_{3}, \mathrm{MgO}, \mathrm{CaO}, \mathrm{Na}_{2} \mathrm{O}$, and $\mathrm{K}_{2} \mathrm{O}$ contents as variables. These were designed to discriminate among four sedimentary provenances. The provenance groups are P1 (mafic) - first cycle basaltic with lesser andesitic detritus; P2 (intermediate)-dominantly andesitic detritus ; P3 (felsic) acid plutonic and volcanic detritus; and P4 (recycled)mature polycyclic quartzose detritus. In this diagram (Fig. 2a), majority of the Baguio District samples plot in the P1 field suggesting a mafic source terrane.

Trace elements Thorium and Scandium are incompatible and compatible, respectively, in igneous differentiation processes. These elements are generally accepted as among the most reliable indicators of sediment provenance because their distribution is less affected by heavymineral fractionation (Taylor and McLennan, 1985). Generally, on a Th/Sc versus Zr/Sc diagram (Fig. 2b), the Zigzag and Klondyke Formations follow a trend of having been derived from mafic rocks that had undergone 
(a)

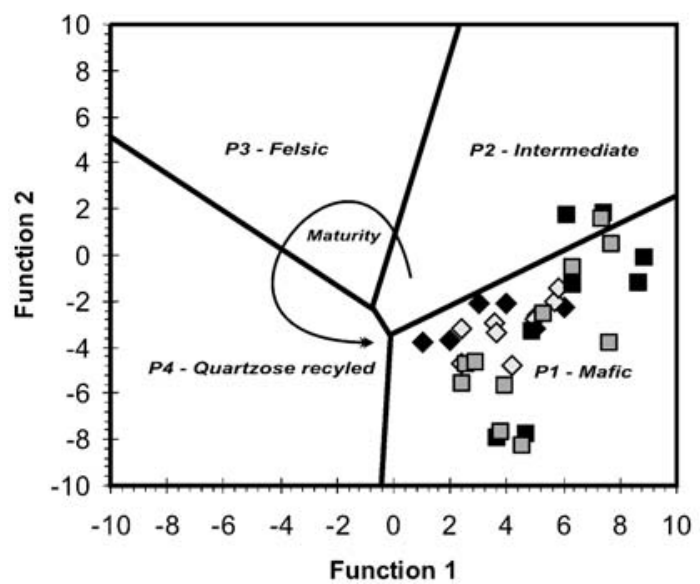

(b)

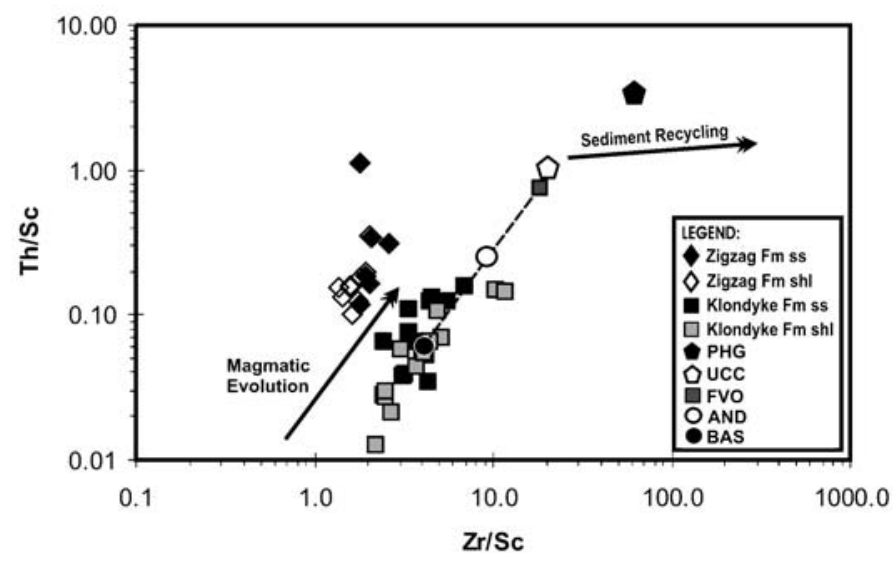

Fig. 2 (a) Major element discrimination plot (Roser and Korsch, 1986) for the Zigzag and Klondyke Formations. Majority of the samples plot in the P1 field suggesting a mafic source terrane. (b) $\mathrm{Th} / \mathrm{Sc}$ versus $\mathrm{Zr} / \mathrm{Sc}$ plot for the Baguio District sedimentary rocks suggests minimal upper crustal input and sediment recycling. Average source compositions are basaltic (after Condie, 1993). BAS, basalt ; AND, andesite ; FVO, felsic volcanics ; UCC, upper continental crust ; PHG, phanerozoic granite (Condie, 1993).

some extent of weathering without significant input from upper crust igneous sources.

\section{Tectonic setting}

The main assumption behind provenance studies is that different tectonic settings contain characteristic rock types which, when eroded, produce sandstones and shales with specific compositional ranges from which the provenance of other samples can be deduced. The major element ratios of $\mathrm{SiO}_{2}-\mathrm{K}_{2} \mathrm{O} / \mathrm{Na}_{2} \mathrm{O}$ seek to separate oceanic island arc environments from those deposited in more evolved arcs (Roser and Korsch, 1986 ; Roser, 2000). The fields are based on ancient sandstone-mudstone pairs, verified against modern sediments from known tectonic settings. Plotting the Baguio District sedimentary rocks on the $\mathrm{SiO}_{2}-\mathrm{K}_{2} \mathrm{O} / \mathrm{Na}_{2} \mathrm{O}$ diagram, the Zigzag Formation mainly plots in the Active Continental Margin and Oceanic Island Arc fields with one outlier plotting in the Passive Margin Field. The Klondyke Formation on the other hand, plots exclusively in the Oceanic Island Arc field (Fig. 3a).

Similarly, various discrimination diagrams based on trace elements are suitable for the determination of tectonic settings (e.g. Taylor and McLennan, 1985 ; Bhatia and Crook, 1986). In the ternary plot of Th-Sc-Zr/10, the sandstones and shales from the Zigzag Formation cluster out of the Oceanic Island Arc Field whereas samples from the Klondyke Formation exclusively plot inside the Oceanic Island Arc field. This result is consistent with the $\mathrm{SiO}_{2}-\mathrm{K}_{2} \mathrm{O} / \mathrm{Na}_{2} \mathrm{O}$ major element diagram of Roser and Korsch (1986) shown earlier.

\section{Conclusions}

The provenance and tectonic setting of Miocene clastic sedimentary rocks from the Zigzag and Klondyke Formations in the Baguio District, Luzon, Philippines were studied using major and trace element analyses. Provenance and tectonic discrimination diagrams reveal that the Zigzag Formation mainly astride the active continental margin and oceanic island arc fields. On the other hand, geochemical data from the Klondyke Formation suggest that the sandstones and shales are strongly dominated by immature, mafic detritus deposited in an oceanic island arc setting. This difference in geochemical signatures suggests a relatively fractionated source for the Zigzag Formation than that of the Klondyke Formation. This "fractionated" character may have been a result of higher sediment reworking for the former than that of the latter as evidenced by higher $\mathrm{Th} / \mathrm{Sc}$ ratios. This result further confirms earlier studies of the Baguio District which suggest that the area had evolved from a marginal basin environment (Zigzag Fm.) to a mature island arc setting (Klondyke Fm.) (Bellon and Yumul, 2000). 

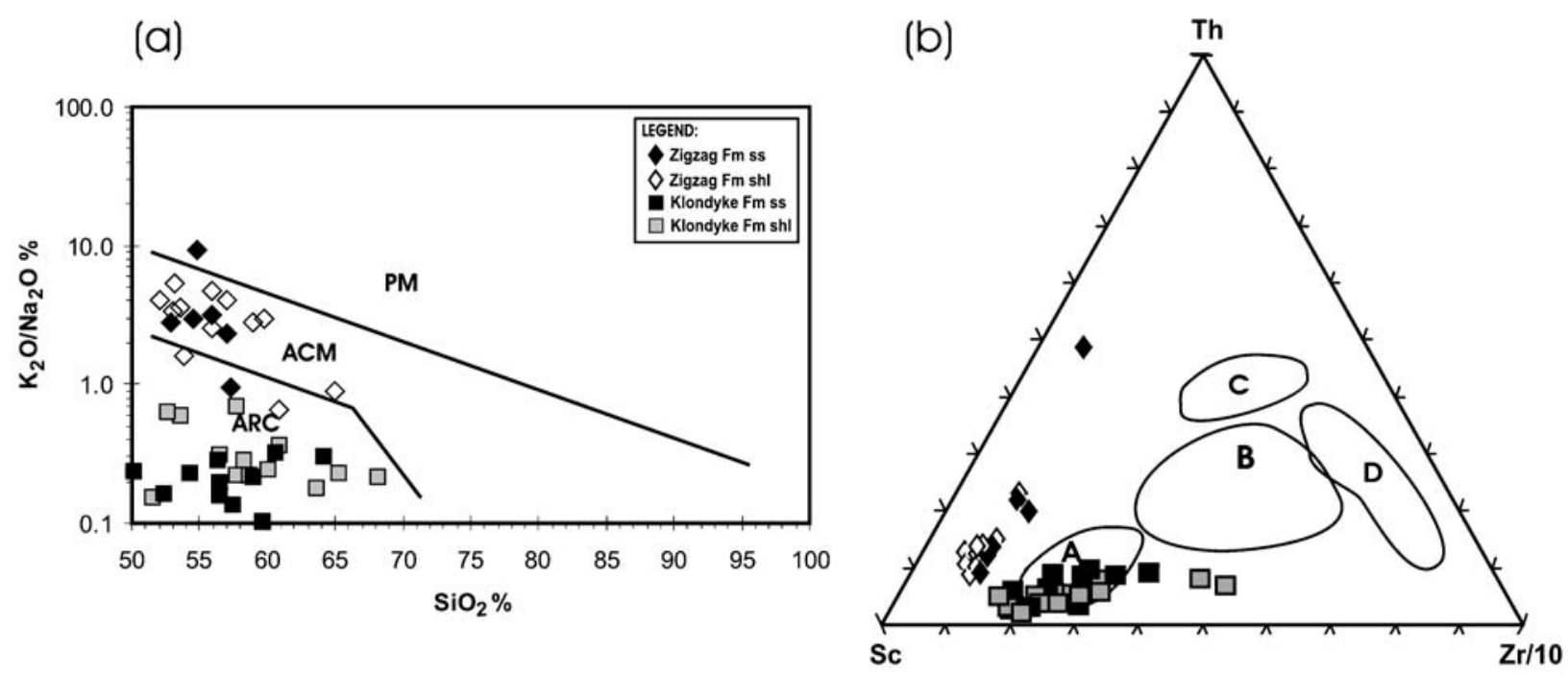

Fig. 3 (a) Discrimination diagrams from Roser and Korsch (1986) ; ARC = oceanic island arc ; ACM=active continental margin ; $\mathrm{PM}=$ passive margin. (b) Th-Sc-Zr/10 ternary diagram (Bhatia and Crook, 1986). $\mathrm{A}=$ oceanic island arc ; $\mathrm{B}=$ continental island arc $; \mathrm{C}=$ active continental margin $; \mathrm{D}=$ passive margin. In both diagrams, the Klondyke Formation consistently exhibits oceanic island arc derivation whereas the Zigzag Formation cluster plots mainly in the active continental margin and oceanic island arc fields.

\section{Acknowledgments}

This work was made possible with financial and logistical support from the National Institute of Geological Sciences-University of the Philippines, University of Hong Kong, Okayama University and the Philippine Council for Industry and Energy Research and DevelopmentDepartment of Science and Technology.

\section{References}

Bellon, H. and Yumul, G.P. Jr., 2000 : Mio-Pliocene Magmatism in the Baguio Mining District (Luzon, Philippines) : age clues to its geodynamic setting. Comptes Rendus Academique Scientiae, 331, 295-302.

Bhatia, M.R. and Crook, K.A.W., 1986 : Trace element characteristics of graywackes and tectonic setting discrimination of sedimentary basins. Contributions to Mineralogy and Petrology, 92, 181-193.

Penña, R.E. and Reyes, M.V., 1970 : Sedimentological study of a section of the "Upper Zigzag" Formation along
Bued River, Tuba, Benguet. Journal of the Geological Society of the Philippines, 24, 1-19.

Condie, K.C., 1993 : Chemical composition and evolution of the upper continental crust; contrasting results from surface samples and shales. Chemical Geology. 104, 1-37.

Roser, B.P. and Korsch, R.J., 1986 : Determination of tectonic setting sandstone-mudstone suites using $\mathrm{SiO}_{2}$ content and $\mathrm{K}_{2} \mathrm{O} / \mathrm{Na}_{2} \mathrm{O}$ ratio. Journal of Geology, 94, 635650.

Roser, B. P., 2000 : Whole-rock geochemical studies of clastic sedimentary suites. Memoirs of the Geological Society of Japan, no. 57, 73-89.

Tamesis, E.V., Lorentz, R.A., Jr., Pascual, R.V., Dizon, E. M., 1982 : Stratigraphy and geologic structures of the Central Valley Basin, Luzon, Philippines. In G.R. Balce, and A.S. Zanoria., eds., Geology and Tectonics of the Luzon-Marianas Region. Proc. CCOP-IOC SEASTAR Workshop, Manila, 83-111.

Taylor, S.R. and McLennan, S.M., 1985 : The Continental crust : its composition and evolution. Oxford Blackwell Scientific Publications, $312 \mathrm{p}$. 


\section{フィリピン，ルソン島バギオ地域に分布する中新統砕屑岩の後背地と テクトニックセッティング : 全岩化学組成による復元}

トマス A タムザサード・鈴木 茂之・グラシアーノ P ユームル ジュニア, 2007, 堆積学研究, No. 64, 27-31

Tomas A. Tam III., Suzuki, S. and Graciano P. Yumul, Jr. : Provenance and tectonic setting of Miocene clastic sedimentary rocks from the Baguio District, Luzon, Philippines :

Evidence from major and trace element geochemistry

Jour. Sed. Soc. Japan, No. 64, 27-31

フィリピン島弧の枠組みが形成されたのは中新世の頃で, 海洋性地殼が発展したものと考えられ ている. 本研究の目的はフィリピン島弧形成期の地質やテクトニックセッティングを推定すること である。試料はフィリピン，ルソン島中央部のバギオ地域に分布する中新統 Zigzag 層と Klondyke 層の砂岩之泥岩で，主要および微量元素について全岩分析を行った，塩基性な組成で，低い $\mathrm{Th} / \mathrm{Sc}$ と $\mathrm{Zr} / \mathrm{Sc}$ の值が得られた。この結果は中新世のフィリピン島弧が玄武岩質な地質からなり, 海洋性 島弧や活動的な大陸縁であったことを支持する。 